\title{
Working Memory Capacity Across L2 Speech Proficiency Levels
}

\section{Capacidade de memória de trabalho através de níveis de proficiência oral em L2}

\author{
Gicele Vergine Vieira Prebianca* \\ Instituto Federal de Educação, Ciência e Tecnologia Catarinense (IFC) \\ Blumenau - Santa Catarina/Brasil \\ Kyria Rebeca Finardi** \\ Universidade Federal do Espírito Santo (UFES) \\ Vitória - Espírito Santo/Brasil \\ Janaina Weissheimer*** \\ Universidade Federal do Rio Grande do Norte (UFRN) \\ Natal - Rio Grande do Norte/Brasil
}

\begin{abstract}
This study investigates whether working memory capacity (WMC) varies across languages and in the course of $\mathrm{L} 2$ speech proficiency levels. Following suggestions in Finardi and Weissheimer (2009) and Prebianca (2010), who found that WMC varied as a function of L2 speech proficiency, the present study assessed three proficiency levels (elementary, intermediate and advanced) and two languages (L1-Portuguese and L2-English). Two WM tests were used, one in the L1 and another in the L2, both in the speaking mode. Sixty adult learners of English as a foreign language participated in the study: 19 elementary, 19 intermediate and 22 advanced learners. Results of Kruskal-Wallis and MannWhitney tests corroborate Finardi and Weissheimer (2009) and Prebianca (2010) suggesting that WMC measured with a speaking span test in L2 seems to conflate the relationship between speech proficiency levels and WMC.
\end{abstract}

KEYWORDS: working memory capacity, L2 speech proficiency level.

RESUMO: Este estudo investiga se a capacidade de memória de trabalho (CMT) varia entre idiomas e níveis de proficiência na fala em L2. Seguindo sugestôes em Finardi e Weissheimer (2009) e Prebianca (2010) que demonstraram que a CMT varia em função do nível de proficiência da fala em L2, o presente trabalho analisou três níveis de proficiência (elementar, intermediário e avançado) e dois

* gicelevpreb@gmail.com.

**kyria.finardi@gmail.com.

*** janaina.weissheimer@gmail.com. 
idiomas (L1-português e L2-inglês). Dois testes de MT foram usados, um em L1 e outro em L2, ambos na modalidade oral. Sessenta estudantes adultos de inglês como língua estrangeira participaram no estudo: 19 elementares, 19 intermediários e 22 avançados. Resultados dos testes Kruskal-Wallis e Mann-Whitney corroboraram Finardi e Weissheimer (2009) e Prebianca (2010) sugerindo que a CMT medida com um teste de amplitude da fala em L2 parece confundir a relação entre níveis de proficiência oral e CMT.

PALAVRAS-CHAVE: capacidade de memória de trabalho, nível de proficiência da fala em L2.

\section{Introduction}

Information processing theory has been used as a framework to study L2 speech in a systematic way for over a decade now (FORTKAMP, 2008). A basic tenet of this approach is that human beings process information under the constraints of a limited capacity cognitive system - working memory (WM) which functions as a computational arena, fueled by limited cognitive resources (attention) that support both the execution of various symbolic computations and the maintenance of intermediate products generated by these computations (JUST; CARPENTER, 1992; MIYAKE; FRIEDMAN, 1998). In this framework, WM is treated as the theoretical construct that refers to the system or mechanism underlying the maintenance of task-relevant information during the performance of a cognitive task (SHAH; MIYAKE, 1999, p. 1).

Research has shown that limitations in individuals' working memory capacity (WMC) may be seen as a possible independent constraint on the processes involved in L1 speech production (DANEMAN; GREEN, 1986; DANEMAN, 1991), L2 speech production (FORTKAMP, 2000; FINARDI; PREBIANCA, 2006; PREBIANCA, 2010; XHAFAJ, 2006) and more recently L2 speech development (FINARDI; WEISSHEIMER, 2009; FINARDI; MOTA, 2012; WEISSHEIMER, 2011; WEISSHEIMER; MOTA, 2009; 2011). These studies have shown that, in general, individuals with a larger WMC tend to outperform those with a smaller capacity in various aspects of language performance and acquisition.

However, the debate over the nature of WMC limitations is still open. At the heart of this discussion is the question of whether individual differences in such a limited capacity system are the result of processing efficiency (DANEMAN; CARPENTER, 1980; BERQUIST, 1998; HARRINGTON, 1992), or due to the availability of attentional resources (CANTOR; ENGLE, 1993; COWAN, 1993; UNSWORTH; ENGLE, 2007). 
The processing efficiency view of WMC (DANEMAN; TARDIF, 1987) posits that the greater an individual's efficiency in processing information, the greater the capacity left available for storage of the products of this processing and of material retrieved from long-term memory. This more efficient processing is believed to be highly task-specific (DANEMAN; GREEN, 1986; DANEMAN, 1991), that is, an individual's WMC will vary according to his/her efficiency in the processes specific to the task with which WMC is being correlated.

One of the most powerful explanations on the nature of WM limitations is the Controlled-Attention View, proposed by Engle and colleagues (TURNER; ENGLE, 1989; CONWAY; ENGLE, 1996; KANE et al., 2001; ENGLE, 2002). The basic argument of this view is that the ability to control attention is the major source of individual differences in WMC, especially in face of conflicts when individuals need to inhibit or suppress irrelevant information during the execution of a cognitive task. In this sense, those with more working memory capacity, the higher spans, as measured by complex span tests such as the reading, the speaking and the operation span tests, are better able to channel attention to specific pieces of information, preventing it to be captured by external and/or internal interfering thoughts (FELDMAN-BARRET et al., 2004).

Regarding the relationship between WMC and speech production, based on Levelt (1989), it is possible to view speech production as a process in which both controlled and automatic processes work in tandem to guarantee the execution of speech. In the specific case of controlled processes in speech production, an individual's capacity to manage attention is believed to be a key aspect in speaking performance (FELDMAN-BARRET et al., 2004).

Within the realms of information processing theories (IPTs), controlled processes, that is, the allocation of attention to specific aspects of a task execution (such as L2 learning) constitute the first necessary steps towards language automatization (MCLAUGHLIN, 1987). Thus, based on this IPTs view of learning and on studies of L2 development (for example, WEISSHEIMER, 2007), we suggest that L2 speech production is a process which requires controlled attention, at least and more so in the early stages of skill development in which practice is indispensable to automatize procedures and free attentional resources to be used by other higher-order processing (MCLAUGHLIN; HEREDIA, 1996). Miyake and Friedman (1998) also suggest that L2 processing (in the case of this paper, speech production) is likely to rely on general learning mechanisms such as, for example WMC, 
more than L1 processing since there is less automatized linguistic knowledge to rely on in the L2.

Following this rationale, a number of researchers (BERQUIST, 1998; FORTKAMP, 1995; FINARDI; WEISSHEIMER, 2009; HARRINGTON, 1992; HARRINGTON; SAWYER, 1992; MIYAKE; FRIEDMAN, 1998, among others), seem to agree that WMC may vary in the course of L2 development as a function of increased command of the language and automatized linguistic knowledge. In bilinguals, the assumption that domain knowledge may impact scores of WMC is based on the low correlations found between measures of WMC in L1 and L2 (for example FINARDI, 2010; PREBIANCA, 2007), which have led researchers to suggest that WM scores in L1 and L2 may be independently motivated to some extent.

Based on evidence that WMC is related to L2 speech performance and development, Finardi and Weissheimer (2009) aimed at verifying whether WMC scores experienced any sort of change in two distinct stages of L2 acquisition, bearing in mind that $\mathrm{L} 2$ processing gets more automatic as a result of increased knowledge of the language. Seventy-nine students of two different federal universities in Brazil were assigned into a basic or an intermediate group, according to their scores in the L2 proficiency test. They were also submitted to an L2 adaptation of Daneman's (1991) speaking span test. It was assumed that the relationship between WMC and speech production would be stronger in basic proficiency levels, in which the controlled processes involved in L2 speaking predominated. It was also assumed that as learners advanced in the L2 development continuum, controlled processes would be gradually automatized and less control (from WM) would be required during L2 speaking in more advanced proficiency levels. Based on these assumptions, Finardi and Weissheimer hypothesized that the means for the intermediate group would be higher than those for the basic group. Besides having confirmed this hypothesis they also found positive and statistically significant correlations between WMC scores and L2 proficiency measures.

In sum, results of Finardi and Weissheimer's study point to the conclusion that WMC seems to vary as a function of L2 speech proficiency. The explanation offered by the researchers for the difference in L2 WMC means (assessed in terms of an L2 speaking span test) across two L2 speaking proficiency levels is aligned with cognitive psychology models of skill development which see the performance on complex cognitive tasks as moving from a more controlled to a more automatized nature (ANDERSON, 
1983; DEKEYSER, 2007), that is to say, in the beginning, learners require more WMC to execute controlled processes which become automatized with practice, thus, freeing up WM resources to be allocated in the execution of other cognitive processes.

Thus, the difference in means found in Finardi and Weissheimer's (2009) study is understood to reflect different levels of automatization of L2 speech production, in the case of the intermediate group reflecting more automatized processes whereas the performance in the basic group would reflect more controlled processes.

According to Fortkamp (1995 apudFINARDI; WEISSHEIMER, 2009), the degree of proficiency learners have in the cognitive task being performed is a problem that researchers dealing with the psychometric correlational approach seem to be circumventing. Fortkamp (1995 apudFINARDI; WEISSHEIMER, 2009) suggests that further investigations can verify this issue more carefully by assessing individuals' WMC in various moments of L2 development and then observing whether this capacity is held constant.

An important step into trying to disentangle this issue is the study conducted by Prebianca (2010), which explored the relationship between lexical access, WMC and proficiency level in L2 speech production. One hundred L1 Brazilian students of English as a foreign language (EFL) performed three WMC tests - the Speaking Span Test in L1 and in L2 and the Operation Span Test in L1 (Ospan); two proficiency tests - an L2 semantic categorization task and the TOEFL iBT Speaking test - and a lexical access task in L2. Multiple regression analyses showed that the predictive power of the L2 SST is rather reduced when entered in the regression model together with a measure of L2 proficiency. This was the case, according to Prebianca (2010), because scores on the L2 SST and L2 proficiency scores were significantly correlated $(\mathrm{r}(100)=.584, \mathrm{p}=000)$. However, when WMC in L2, as measured by the L2 SST, was inserted in the regression model as a separate set of predictors (apart from proficiency), its main effect proved to be statistically significant in explaining bilingual lexical access.

Another relevant finding in Prebianca (2010) was revealed by zero order and partial correlations run with the two proficiency variables obtained. The analyses indicated that L2 proficiency significantly explains a proportion of the variance in WMC, as measured by the SST in L2. The shared contribution of both proficiency measures to the L2 SST was 19\%, supporting the claim that the L2 SST is somehow conflated with learners' L2 proficiency level. 
Building mainly on Finardi and Weissheimer (2009) and Prebianca (2010), the present study aims at adding evidence to the thorny issue of variations in WMC in $\mathrm{L} 2$ by analyzing the relationship between WMC across languages and L2 speech proficiency levels using two languages and three proficiency levels. Based on the evidence that WMC is related to L2 speech performance and development, the focus of the present investigation is to verify whether WMC scores measured in L1 and L2 experience any sort of change in three distinct stages of $\mathrm{L} 2$ acquisition, assuming that $\mathrm{L} 2$ processing gets more automatic as a result of increased knowledge on the language.

\section{Methods}

\subsection{Participants}

In order to verify the extent to which WMC measured by a speaking span test in L1 and in L2 can help to understand L2 speech development, two WM tests were used, one in the L1 and another in the L2, both in the speaking mode. Sixty young adult learners of English as a foreign language participated in the study: 19 elementary, 19 intermediate and 22 advanced learners. No standardized proficiency test was applied in the present study though participants did an in-house proficiency test before starting their language courses. The criterion used for assigning them to different proficiency groups was to verify in which level students were enrolled at their English courses a week previous to data collection.

\subsection{Data collection and analysis}

\subsubsection{The Speaking Span Test - L1 and L2}

The monolingual version of the SST used in this study was partially adapted by Prebianca (2007), following the original version designed by Fortkamp (1999). The test consists of 60 unrelated words presented in sets of 2, 3, 4, 5 and 6 words each. Each 7-letters long word remains in the center of a computer screen for 1 second and is replaced by another one after each 10 milliseconds. After all words of a specific set have been presented, question marks appear on the computer screen and are followed by a noise which signals the moment when participants need to start formulating the oral sentences for each word they had seen in a particular set. 
The L2 version of the SST used in this study, adapted from Fortkamp (1999), similarly to the Portuguese version, also requires learners to memorize L2 words for further use in the oral production of $\mathrm{L} 2$ sentences. The test also consists of 60 unrelated words presented in increasing sets from to 2 to 6 words, which appear to participants in just the same way and time as in the $\mathrm{L} 1$ version. Individual measures of WMC in L1 and in L2 were calculated based on the total number of words for which participants were able to produce a grammatical and coherent sentence using the words previously memorized (see Appendix A for the stimuli for both SST tests and Appendix $B$ for participants' individual scores).

The data were submitted to statistical analyses so as to determine whether the means for WMC measures (both in L1 and in L2) are significantly different for each proficiency level.

\section{Results}

In order to investigate whether $\mathrm{L} 2$ proficiency accounts for any variance in WMC scores, descriptive statistics for the scores on the L1 and L2 SST in the three levels of L2 proficiency were run. Table 1 displays the results.

TABLE 1

Descriptive Statistics for L1 SST and L2 SST variables in the Elementary, Intermediate and Advanced groups

\begin{tabular}{|c|c|c|c|c|c|c|c|c|}
\hline & Min & Max & Mean & SD & Skewness & Std. Error & Kurtosis & Std. Error \\
\hline $\begin{array}{l}\text { Elementary } \\
\text { Group } \\
\text { WMCL1 } \\
\text { WMCL2 } \\
\mathrm{N}=19\end{array}$ & $\begin{array}{c}19.67 \\
6.00\end{array}$ & $\begin{array}{l}39.00 \\
22.67\end{array}$ & $\begin{array}{l}29.52 \\
15.54\end{array}$ & $\begin{array}{l}5.10 \\
4.68\end{array}$ & $\begin{array}{l}-.064 \\
-.491\end{array}$ & $\begin{array}{l}.524 \\
.524\end{array}$ & $\begin{array}{l}-.067 \\
-.585\end{array}$ & $\begin{array}{l}1.014 \\
1.014\end{array}$ \\
\hline $\begin{array}{l}\text { Intermediate } \\
\text { Group } \\
\text { WMCL1 } \\
\text { WMCL2 } \\
\mathrm{N}=19\end{array}$ & $\begin{array}{l}8.00 \\
4.00\end{array}$ & $\begin{array}{l}32.00 \\
20.00\end{array}$ & $\begin{array}{l}22.94 \\
11.94\end{array}$ & $\begin{array}{l}6.49 \\
4.71\end{array}$ & $\begin{array}{l}-.679 \\
-.009\end{array}$ & $\begin{array}{l}.524 \\
.524\end{array}$ & $\begin{array}{c}.228 \\
-.725\end{array}$ & $\begin{array}{l}1.014 \\
1.014\end{array}$ \\
\hline $\begin{array}{l}\text { Advanced } \\
\text { Group } \\
\text { WMCL1 } \\
\text { WMCL2 } \\
\mathrm{N}=22\end{array}$ & $\begin{array}{c}15.00 \\
7.00\end{array}$ & $\begin{array}{l}42.00 \\
38.00\end{array}$ & $\begin{array}{l}28.31 \\
19.77\end{array}$ & $\begin{array}{l}6.32 \\
7.75\end{array}$ & $\begin{array}{l}.061 \\
.443\end{array}$ & $\begin{array}{l}.491 \\
.491\end{array}$ & $\begin{array}{l}.077 \\
.375\end{array}$ & $\begin{array}{l}.953 \\
.953\end{array}$ \\
\hline
\end{tabular}


As Table 1 shows, WMC scores were found to be non-normally distributed for all proficiency groups. In the elementary and advanced proficiency groups only the scores for WMC in L2 presented skewness and kurtosis problems; whereas in the intermediate group, scores for both WMC in L1 and in L2 had skewness and kurtosis problems, respectively.

The highest possible scores for WMC in L1 and in L2 were both obtained by the advanced group -42.00 and 38.00 respectively. In addition, all three proficiency groups presented a better performance in the $\mathrm{L} 1$ version of the WMC test, as revealed by minimum and maximum scores. This tendency seems to be confirmed by the mean difference between measures of WMC, both in L1 and in L2, in the three proficiency groups. In order to check whether this mean difference was statistically significant, a KruskalWallis non-parametric statistical test was applied to the data. Results can be seen in Table 2.

\section{TABLE 2}

Kruskal-Wallis test for L1 and L2 WMC scores in the Elementary,

Intermediate and Advanced groups

\begin{tabular}{lllc}
\hline & Proficiency Level & N & Mean Rank \\
\hline WMCL1 & & & \\
& Elementary Group & 19 & 35.08 \\
& Intermediate Group & 19 & 18.82 \\
& Advanced Group & 19 & 33.11 \\
& & 57 & \\
\hline WMCL2 & & & \\
& Elementary Group & 19 & 28.89 \\
& Intermediate Group & 19 & 18.08 \\
& Advanced Group & 19 & 40.03 \\
& & 57 & \\
\hline
\end{tabular}

\begin{tabular}{lcc}
\hline Test Statistics & WMCL1 & WMCL2 \\
\hline Chi-Square & $\mathbf{1 0 . 8 8 9}$ & $\mathbf{1 6 . 6 4 1}$ \\
df & 2 & 2 \\
Asymp. Sig. &. $\mathbf{0 0 4}^{*}$ & $\mathbf{. 0 0 0 ^ { * }}$ \\
\hline${ }^{*} \mathrm{p}<0,05$ & & \\
\hline
\end{tabular}

As can be observed in Table 2, the Kruskal-Wallis analysis indicates there is a significant difference in the L1 and L2 WMC medians among the three proficiency groups, $\mathrm{X}^{2}(2, N=57)=10.88, p=.004$ and $\mathrm{X}^{2}(2, N=57)=$ $16.64, p=.000$, respectively. The proportion of variability in the ranked 
dependent variables (WMCL1 and WMCL2) accounted for by proficiency level was .19 and .29, respectively, indicating a stronger relationship between WMC and level of proficiency in the L2. This difference in variability in WMC in L1 and L2 is in line with results in Prebianca (2010), and seems to support Miyake and Friedman's (1998) claim that L2 processing requires more attention to be executed whereas L1 processing tends to be more automatized, thus yielding differences in WMC scores in the two languages. We will explore this issue further in the Discussion session.

In addition, these results also seem to confirm the hypothesis that $\mathrm{L} 2$ WMC, as measured by the L2 SST, is influenced by the amount of domainknowledge one has in that language, i.e. his/her proficiency level, as put forward by Harrington (1992); Berquist (1998); Harrington and Sawyer (1992), Fortkamp (1995); Finardi and Weissheimer (2009); Miyake and Friedman (1998), Prebianca (2010), among others. We will return to this discussion later.

Because the overall Kruskal-Wallis test proved to be statistically significant, pairwise comparisons were run so as to attest statistical significance to the patterns of WM variation found in the data. Tables 3 and 4 display the results of the Mann-Whitney $U$ test for L1 and L2 WMC across proficiency levels.

\section{TABLE 3}

Pairwise comparisons between L1 WMC and proficiency groups

\begin{tabular}{lccc}
\hline \multicolumn{4}{c}{$\begin{array}{c}\text { Group differences for } \\
\text { Mean Rank }\end{array}$} \\
\cline { 2 - 5 } & $\mathrm{U}$ & $\mathrm{z}$ & Sig. (2-tailed) \\
\cline { 2 - 5 } Elementary Group X Intermediate Group & 81.0 & -2.90 & $.004^{*}$ \\
Intermediate Group X Advanced Group & 86.50 & -2.75 & $.006^{*}$ \\
Elementary Group X Advanced Group & 164.50 & -.468 & .640 \\
\hline $\mathrm{N}=19$ (for each proficiency group) & & & \\
${ }^{*} \mathrm{p}<0,05$ & & & \\
\hline
\end{tabular}


TABLE 4

Pairwise comparisons between L2 WMC and proficiency groups

\begin{tabular}{lccc}
\hline \multicolumn{3}{c}{$\begin{array}{c}\text { Group differences for } \\
\text { Mean Rank }\end{array}$} & \\
\hline & $\mathrm{U}$ & $\mathrm{z}$ & Sig. (2-tailed) \\
\cline { 2 - 4 } & 105.00 & -2.20 & $.027^{*}$ \\
Elementary Group X Intermediate Group & 48.50 & -3.86 & $.000^{*}$ \\
Intermediate Group X Advanced Group & 103.00 & -2.26 & .024 \\
Elementary Group X Advanced Group & & & \\
\hline $\mathrm{N}=19$ (for each proficiency group) & & & \\
${ }_{\mathrm{*}}^{\mathrm{p}<0,05}$ & & & \\
\hline
\end{tabular}

As shown in Table 3, follow-up analyses indicated a statistically significant difference for L1 WMC scores between the elementary and the intermediate groups and between the intermediate and the advanced ones. No statistically significant difference was found for the same scores between the elementary and the advanced group. Pairwise comparisons for L2 WMC scores, on the other hand, showed statistically significant differences between all three proficiency groups: elementary versus intermediate, intermediate versus advanced, and elementary versus advanced, as can be observed in Table 4.

\section{Discussion}

The fact that the elementary group outperformed the intermediate one in both versions of the WMC test might be due to the presence of more higher-span than lower-span individuals within this group, which may also explain the advanced group's better performance in the L1 and L2 SST over the intermediate group. However, the finding that no significant difference was found for the mean ranks of WM in L1 between the elementary and the advanced groups, but was so in L2, indicates that WMC in L1 and L2 seem to rely on distinct abilities, offering support to the hypothesis that level of domain-knowledge (i.e. proficiency) in the $\mathrm{L} 2$ may explain a portion of the variation in L2 WMC scores (FINARDI; WEISSHEIMER, 2009; FINARDI, 2010; PREBIANCA, 2010; WEISSHEIMER; MOTA, 2011).

Indeed, this finding, certainly the most important in this study, is in line with Prebianca's (2010), which demonstrated that 19\% of the L2 SST variation was accounted for by proficiency level in the L2. As advocated by Prebianca (2010), lexical access, the main process driving speech production (LEVELT, 1989), qualifies as a serial search task which requires a number of controlled attention sub-processes in order to be successfully performed. In 
other words, proficiency level (processing automatization ${ }^{1}$ ) might interfere with the quality of the sub-processes involved in L2 speaking, especially the ones underlying sentence formulation and lexical retrieval, such as (i) delimiting the lexicon search set adequately so as to restrict the number of lexical options; (ii) selecting the lexical item that fits the intended message and; (iii) monitoring the selection outcome. If L2 speakers are not proficient enough it is probable they will face great difficulties to execute these subprocesses as for they will need to resort to a greater amount of attentional resources to perform each step of retrieving the right words, thus overloading working memory capacity. If we consider that so as to produce L2 sentences orally speakers have to undergo a number of processes, among which are the need to hold many memory representations (especially the lexical items just retrieved) active in the focus of attention by blocking interfering stimuli while assembling them into a specific verbalization order so as to give them a phonetic shape; lack of automatized language processing routines (hereby understood as proficiency) might be extremely harmful to the production of fluent, mistakes-free speech, once more controlled attention will be needed to achieve a good performance on the task.

Results of our study also allow us to contribute with insights to the discussion on what WM tests really seem to measure. Unsworth, Redick, Heitz, Broadway and Engle (2009) have raised the potential significance of processing time, processing accuracy and correct recall (storage) measures when looking for the relationship between WMC and high-level cognition, instead of only examining the storage index. Ideally, as claimed by the authors, the processing indexes (time and accuracy) also contribute to form a global measure of WMC, as initially theorized for complex span tasks regarding the function of processing and storage of information in WM and should, therefore, be investigated.

Unsworth et al. (2009) revealed that higher spans, the ones with higher measures of recall, were also the ones who processed information faster and more accurately. Moreover, results also showed that processing time and processing accuracy do not reflect the same construct - processing efficiency-, as suggested

\footnotetext{
${ }^{1}$ To reiterate, in our view, L2 proficiency relates to knowledge of the foreign language, which develops in a continuum from a more controlled to a more automatic performance. This view is in line with assumptions of the Cognitive Theory which sees L2 learning as the learning of a complex skill, being composed of sub-skills which can become routinized through practice (MCLAUGHLIN, 1987).
} 
by some WMC theories (e.g. CONWAY; ENGLE, 1996; ENGLE et al., 1992 apud UNSWORTH et al., 2009). On the contrary, they both presented unique contribution to high-order cognitive performance (fluid intelligence $-\mathrm{gF}-$ in this case), independently of each other. Despite the contribution of processing time and processing accuracy to $\mathrm{gF}$ scores variation, processing indexes did not fully mediate the relation between fluid intelligence and storage, suggesting that recall measures still relate to high-order cognition when partialling out processing efficiency. Unsworth et al. (2009) concluded that the variance in $\mathrm{gF}$ accounted for by processing time and accuracy reflect either some variance shared by both tasks - the complex span and the $\mathrm{gF}$ tests applied, or more basic differences in processing abilities. This suggestion is in line with Kane, Conway and Engle's (1999) claims about what WM complex span tests really measure (see details below in this discussion session).

Based on what has been discussed so far, we are inclined to agree that the construct of WM seems to be closely tied to the tasks that are used to measure it and also to the language in which participants are tested (HAMBRICK; ENGLE, 2002). Domain-specific span tests, like the one used in this study, predict that an individual who has processing expertise in a specific domain (in our case, L2 speaking) should have more attentional resources available for the storage components involved in the speaking span task, since this expertise can facilitate processing and thus free up attention to be focused on the maintenance of task relevant information. However, such domain-specific WM tasks have been challenged by a number of researchers (for example FELDMAN-BARRET; TUGADE; ENGLE, 2004) based on evidence which shows that people tend to perform consistently across several span tasks that require different types of computations to be made (e.g. mental rotation, arithmetic problems, sentence reading).

Kane, Conway and Engle (1999) explain that neither complex span task can provide a pure index of WMC once the working memory system is a composite of domain-specific and domain-general controlled attention abilities. Individual differences in $\mathrm{WMC}$ can then be influenced by individuals' personal skills on a particular processing, by their ability to keep relevant pieces of information activated in memory in face of distraction, or by both. However, what sustains the relationship between complex span measures and high-order cognitive processes is, according to the researchers, the outcome of the domaingeneral controlled attention component of WM (KANE, CONWAY; ENGLE, 1999). Therefore, we claim that, in the present study, the L2 SST used might have measured participants' proficiency in the additional language (domain- 
specific knowledge) and not exclusively WMC, as our data suggest, since results show an opposite pattern for the L1 version of the test, which may have actually tackled participants' general attention control processes. In an attempt to minimize the issue of domain-specific versus domain-general abilities, complex span tasks that differ in the domain-specific component (for example the OSPAN) can be administered in future studies.

Evidence for a WMC and proficiency level interaction was also found in a recent study conducted by Van den Noort, Bosch and Hugdahl (2006). L1 speakers of Dutch who had German and Norwegian as their L2 and L3, respectively, performed three WM tasks - a simple one that taps the storage component only (the digit-span task) and two complex span tasks that encompass storage and processing (the reading-span and the letter-number ordering task). In general, their results showed that differences in performance between L1 and the foreign languages can be found on both simple and complex working memory tasks, supporting the hypothesis that working memory capacity interacts with language proficiency (p. 295).

Moreover, Van den Noort, Bosch and Hugdahl's (2006) findings suggest that the relationship between WMC and foreign language proficiency might be language-specific, since their study was conducted with learners of languages that belong to the same linguistic group, for instance, the Germanic one. Therefore, researchers emphasize that it would be interesting to assess WM in languages that belong to different linguistic groups. In this sense, the results of our study, at first glance, seem to refute the language-specific hypothesis proposed by Van den Noort, Bosch and Hugdahl (2006), once our data also showed that learners had a better performance on the L1 (Portuguese) version of the speaking span test if compared to the L2 version (English). In other words, the interaction between working memory capacity and proficiency level in the foreign language seem not to be language-specific, as the L1 and L2 languages tested in our study indeed belong to different linguistic groups (the Roman and Germanic ones, respectively). The discussion of WM assessment procedures is crucial in the field of Applied Linguistics, since comparing studies with distinct research designs (for instance, different languages and language groups) may lead to caveats and misconceptions as pointed out elsewhere (JUFFS; HARRINGTON, 2011; WEN, 2012).

In sum, results in our study indicate that, although participants' performance in the L 2 speaking span task seems to have been influenced by specific processing competencies (i.e. proficiency in L2), they did not fully account for the variability in SST scores, since it is likely that participants also 
differed in their domain-general ability to control attention. This only adds to the heated discussion on complex working memory span tasks and their relation to measures of higher-order cognition. It also suggests that debates focusing on the multifaceted nature of WMC and its relation to the complex skills are unlikely to be resolved by a single explanatory theory, such as processing efficiency or attentional view, but rather, by a combination of empirical data and theoretical accounts. Unsworth et al. (2009, p. 651) reinforce this idea,

More work is needed to examine the multifaceted nature of working memory and to provide a finer-grained breakdown of the different working memory processes that influence not only performance on the complex span tasks, but also influence performance on all those tasks that have been found to be dependent on working memory. Only when all components of working memory are successfully integrated into the same model will we have a fuller understanding of working memory functioning.

In fact, Unsworth et al. have raised their voices to alert us that WM is not an undifferentiated pool of resources but rather that it represents a set of unique processes. They also claimed that a theory is needed to encompass all the components (recall, processing accuracy, processing time) and subcomponents in a single model acknowledging the fact that each component influences the others at the same time that it accounts for unique variance (2009, p. 651).

\section{Conclusion}

This study set out to investigate whether WMC varies across languages and in the course of L2 speech proficiency levels. Results have allowed us to conclude that WMC measured with a speaking span test in L2 seems to conflate the relationship between proficiency level and WMC, corroborating findings in Prebianca (2010) and Finardi and Weissheimer (2009).

This study does not go without some limitations. First of all, the lack of standardized proficiency test makes it hard for the researchers to argue in favor of a definite baseline. Further research should consider applying a proficiency test as a way of guaranteeing that all participants share the same level. In addition, the small sample size did not allow researchers to apply parametric statistical tests; therefore, results are less prone to generalization. 
Besides, this study counted on different populations of learners (crosssectional); more reliable results could be generated by a longitudinal methodological design which, unfortunately, was out of the scope of this study. Longitudinal methodologies allow to trace the same participants from elementary to advanced levels, thus, providing more reliability to the data. Finally, future studies might consider using the Ospan test instead of the Speaking span test to verify which results might be yielded by a span test that does not include a language-specific processing component.

All in all, although we believe this study has shed some light on the problematic issue of whether or how proficiency conflates WMC scores, we also acknowledge that more research is surely warranted to fully understand the interface between WM and L2 speech production and development.

\section{References}

ANDERSON, J. R. The Architecture of Cognition. Cambridge, MA: Harvard University Press, 1983.

BERQUIST, B. Individual Differences in Working Memory Span and L2 Proficiency: Capacity or Processing Efficiency? Paper presented at the American Association for Applied Linguistics, 1998.

CANTOR, J.; ENGLE, R. Working Memory Capacity as Long-Term Memory Activation: An Individual-Differences Approach. Journal of Experimental Psychology: Learning, Memory and Cognition, v. 19, n. 5, p. 1101-1114, 1993.

COWAN, N. Activation, Attention and Short Term Memory. Memory and Cognition, v. 2, n. 2, p. 162-167, 1993.

CONWAY, A.; ENGLE, R. Individual Differences in Working Memory Capacity: More Evidence for a General Capacity Theory. Memory, v. 4, p. 577-590, 1996.

DANEMAN, M. Working Memory as a Predictor of Verbal Fluency. Journal of Psycholinguistic Research, v. 20, p. 445-464, 1991.

DANEMAN, M.; GREEN, I. Individual Differences in Comprehending and Producing Words in Context. Journal of Memory and Language, v. 25, p. 1-18, 1986. DANEMAN, M.; CARPENTER, P. Individual Differences in Working Memory and Reading. Journal of Verbal Learning and Verbal Behaviour, v. 19, p. 450-466, 1980.

DANEMAN, M.; TARDIF, T. Working Memory and Reading Skill Re Examined. In: COLTHEART, M. (Ed.). Attention and Performance 12: The Psychology of Reading. Hillsdale, NJ: Lawrence Erlbaum, 1987. p. 491-508. 
DEKEYSER, R. Practice in a Second Language: Perspectives from Applied Linguistics and Cognitive Psychology. Cambridge: Cambridge, 2007.

ENGLE, R. Working Memory Capacity as Executive Attention. Current Directions in Psychological Science, v. 11, p. 19-23, 2002.

FELDMAN-BARRETT, L.; TUGADE M. M.; ENGLE, R. W. Individual Differences in Working Memory Capacity and Dual-Process Theories of the Mind. Psychological Bulletin, v. 130, n. 4, p. 553-573, 2004.

FINARDI, K. Working Memory Capacity in Second Language Learning. 1. ed. Saarbrucken: Lambert Academic Publishing AG \& Co.KG, 2010.

FINARDI, K.; PREBIANCA, G. Working Memory Capacity and Speech Production in L2: Evidence from a Picture Description Task. Revista de Estudos da Linguagem, v. 14, p. 231-260, 2006.

FINARDI, K.; WEISSHEIMER, J. On the Relationship Between Working Memory Capacity and L2 Speech Development. Signótica, v. 20, p. 367-391, 2009.

FINARDI, K.; MOTA, M. The Acquisition of a Syntactic Structure in L2 Speech: The Role of Working Memory Capacity. RLA. Revista de Linguistica Teórica y Aplicada (Impressa), v. 50, p. 119-138, 2012.

FORTKAMP, M.B.M. Working Memory Capacity and Fluent L2 Speech Production. (Master's thesis) - Universidade Federal de Santa Catarina, Florianópolis, 1995. Unpublished.

FORTKAMP, M. B. M. Working Memory Capacity and Elements of L2 Speech Production. Communication and cognition, v. 32, p. 259-295, 1999.

FORTKAMP, M. B. M. Working Memory Capacity and L2 Speech Production: An Exploratory Study. Doctoral dissertation - Department of English. Universidade Federal de Santa Catarina, 2000.

FORTKAMP, M. B. M. Aspectos cognitivos da aprendizagem de LE: entendendo a memória de trabalho. In: ALVARES, K.A.D.S.M.L.O. Perspectivas de investigação em Linguística Aplicada: estudos em homenagem ao Professor Dr. José Carlos Paes de Almeida Filho, v. 2. Campinas: Pontes Editores. 2008. p. 267-284.

HAMBRICK, D. Z.; ENGLE, R.W. Effects of Domain Knowledge, Working Memory Capacity, and Age on Cognitive Performance: An Investigation of the Knowledge-Is-Power Hypothesis. Cognitive Psychology, v. 44, p. 339-387, 2002. HARRINGTON, M. Working Memory Capacity as a Constraint on L2 Development. In: HARRIS, R. J. (Ed.). Cognitive Processing in Bilinguals. Amsterdam: Elsevier, 1992. 
HARRINGTON, M.; SAWYER, M. L2 Working Memory Capacity and L2 Reading Skills. Studies in Second Language Acquisition, v. 14, n. 1, p. 25-38, 1992.

JUFFS, M.; HARRINGTON, M. Aspects of Working Memory in Second Language Learning and Teaching. Language Teaching, v. 44, p. 137-166, 2011. JUST, M.; CARPENTER, P. A Capacity Theory of Comprehension: Individual Differences in Working Memory. Psychological Review, v. 98, p. 122-149, 1992. KANE, M. J.; CONWAY, A. R. A.; ENGLE, R. W. What Do Working-Memory Tests Really Measure? Behavioral and Brain Science, v. 22, n. 1, 1999.

KANE, M. J., BLECKLEY, K. M., CONWAY, A. R. A.; ENGLE, R. W. A Controlled-Attention View of Working-Memory Capacity. Journal of Experimental Psychology: General, v. 130, p. 169-183, 2001.

LEVELT, W. Speaking: From Intention to Articulation. Cambridge, MA: MIT Press. 1989.

MCLAUGHLIN, B. Theories of Second-Language Learning. London: Edward Arnold Publishers Ltd., 1987.

MCLAUGHLIN, B.; HEREDIA, R. Information-Processing Approaches to Research on Second Language Acquisition and Use. In: RITCHIE, B.W. (Ed.). Handbook of Second Language Acquisition. San Diego: Academic Press, 1996. p. 213-228.

MIYAKE, A.; FRIEDMAN, N. F. Individual Differences in Second Language Proficiency: Working Memory as Language Aptitude. In: HEALY, A.F.; BOURNE, L.E. (Eds.). Foreign Language Learning: Psycholinguistic Studies on Training and Retention. Mahwah, NJ: Erlbaum, 1998. p. 339-364.

PREBIANCA, G. Working Memory Capacity, Lexical Access and Proficiency Level In L2 Speech Production: An Exploratory Study. (Unpublished research paper). Department of English. Universidade Federal de Santa Catarina, Florianópolis. 2007.

PREBIANCA, G. Working Memory Capacity and Foreign Language Speech Production: A Look at Lexical Access Processes and Level of Proficiency. 1. ed. Saarbrücken: LAP Lambert Academic Publishing AG \& Co. KG, 2010.

SHAH, O.; MIYAKE, A. Models of Working Memory: An Introduction. In: MIYAKE, A.; SHAH, P. (Eds.). Models of Working Memory: Mechanisms of Active Maintenance and Executive Control. Cambridge, UK: Cambridge University Press, 1999. p. 1-27.

TURNER, N.; ENGLE, R. Is Working Memory Capacity Task-Dependent? Journal of Memory and Language, v. 28, p. 127-154, 1989. 
UNSWORTH, N.; ENGLE, R.W. Individual Differences in Working Memory Capacity and Retrieval: A Cue-Dependent Search Approach. In: NAIRNE, J. S. (Ed.). The Foundation of Remembering: Essays in Honor of Henry L. Roediger, III. New York: Psychology Press, 2007. p. 241-258.

UNSWORTH, N.; REDICK, T. S.; HEITZ, R. P.; BROADWAY, J. M.; ENGLE, R. W. Complex Working Memory Span Tasks and Higher-Order Cognition: A Latent-Variable Analysis of the Relationship Between Processing and Storage. Memory, v. 17, n. 6, p. 635-654, 2009.

VAN DEN NOORT, M. W. M. L.; BOSCH, M. P. C.; HUGDAHL, K. Foreign Language Proficiency and Working Memory Capacity. European Psychologist, v. 11, n. 4, p. 289-296, 2006.

WEISSHEIMER, J. Working Memory Capacity and the Development of L2 Speech Production. (Doctoral dissertation) - Department of English. Universidade Federal de Santa Catarina, Florianópolis. 2007.

WEISSHEIMER, J.; MOTA, M. Individual Differences in Working Memory Capacity and the Development of L2 Speech Production. Issues in Applied Linguistics, v. 17, p. 34-52, 2009.

WEISSHEIMER, J. The Role of Working Memory Capacity in the Development of L2 Speech Production. Ilha do Desterro (UFSC), v. 60, p. 75-104, 2011.

WEISSHEIMER, J.; MOTA, M. Working Memory Capacity and Lexical Density in L2 Speech Production. Organon (UFRGS), v. 51, p. 267-290, 2011. WEN, Z. Working Memory and Second Language Learning. International Journal of Applied Linguistics, v. 22, n. 1, p. 1-22, 2012.

XHAFAJ, D. Pause Distribution and Working Memory Capacity in L2 Speech Production. 2006. (Master's thesis) - Department of English. Universidade Federal de Santa Catarina, Florianópolis. 


\section{Appendix A - Stimuli for both SST tests}

\section{The SST in L1 - list of words}

\begin{tabular}{|l|c|c|}
\hline Test 1 & Test 2 & Test 3 \\
\hline Direção & Memória & Relógio \\
\hline Matéria & Assalto & Correio \\
\hline & & \\
\hline Cerveja & Galinha & Telhado \\
\hline Exilado & Decreto & Chinelo \\
\hline Árvores & Estação & Planeta \\
\hline & & \\
\hline Nataçāo & Bondade & Cortina \\
\hline Cadeira & Teatral & Desenho \\
\hline Palhaço & Suborno & Abóbora \\
\hline Estrela & Caminho & Inverno \\
\hline & & \\
\hline Besouro & Beliche & Lixeira \\
\hline Polícia & Viveiro & Cimento \\
\hline Camisas & Caderno & Azulejo \\
\hline Amizade & Laranja & Pássaro \\
\hline Revista & Bordado & Toalhas \\
\hline & & \\
\hline Padaria & Estádio & Papelão \\
\hline Violino & Gráfica & Cérebro \\
\hline Leitura & Perfume & Remédio \\
\hline Tesouro & Aquário & Abelhas \\
\hline Futebol & Redação & Estrada \\
\hline Cozinha & Lâmpada & Nublado \\
\hline
\end{tabular}




\section{The SST in L2 - list of words}

\begin{tabular}{|l|c|c|c|c|c|}
\hline Practice 1 & Practice 2 & Practice 3 & Test 1 & Test 2 & Test 3 \\
\hline House & People & Boss & Arm & Spoon & Ball \\
\hline Beach & Earth & Island & Course & Bank & Tool \\
\hline School & Soccer & Tea & Guy & Date & Ice \\
\hline Hobby & Wife & Mouth & Point & Gas & Bread \\
\hline Family & Power & Sport & Train & Sky & Sea \\
\hline & & & & & \\
\hline Team & World & Baby & Cow & Car & Bag \\
\hline Night & Summer & Idea & Fire & Dog & Year \\
\hline Friend & Ocean & Movie & Shoe & Disk & King \\
\hline Music & Apple & Space & Key & Pen & Band \\
\hline & & & & & \\
\hline Snack & Ball & Gift & Snow & Bird & Flag \\
\hline Drug & Nurse & Clock & Oil & Seat & Job \\
\hline Honey & truck & Woman & Door & Bath & Air \\
\hline Light & Actress & Taxi & Boat & Girl & Brain \\
\hline Face & Room & Fish & Toy & Club & Boy \\
\hline & & & & & \\
\hline Coffee & Worker & Milk & Art & Street & Class \\
\hline Mother & Dress & Problem & Box & Bed & Farm \\
\hline Prison & Head & Window & Floor & Mind & Bus \\
\hline Number & City & Lunch & Rock & Mail & TV \\
\hline Flower & Plant & Party & Coat & Beer & File \\
\hline Poem & Moon & Money & Book & Pair & Crowd \\
\hline
\end{tabular}




\section{Appendix B - Participants' individual scores on the Speaking Span Test}

Individual Scores on the L1 SST

\begin{tabular}{|c|c|c|r|c|c|}
\hline \multicolumn{2}{|c|}{ Elementary Group } & \multicolumn{2}{c|}{ Intermediate Group } & \multicolumn{2}{c|}{ Advanced Group } \\
\hline Part. & & Part. & & Part. & \\
\hline 1 & 25,67 & 1 & 24,00 & 2 & 34,00 \\
\hline 2 & 32,33 & 7 & 31,00 & 3 & 24,00 \\
\hline 3 & 26 & 8 & 26,00 & 4 & 25,00 \\
\hline 4 & 19,67 & 9 & 27,00 & 5 & 35,00 \\
\hline 5 & 30,33 & 11 & 12,00 & 6 & 15,00 \\
\hline 6 & 38 & 12 & 22,00 & 10 & 26,00 \\
\hline 7 & 21 & 13 & 20,00 & 14 & 22,00 \\
\hline 8 & 30 & 17 & 25,00 & 15 & 38,00 \\
\hline 9 & 39 & 19 & 22,00 & 16 & 33,00 \\
\hline 10 & 28,33 & 22 & 24,00 & 18 & 29,00 \\
\hline 11 & 26,33 & 23 & 32,00 & 20 & 27,00 \\
\hline 12 & 34,33 & 24 & 8,00 & 21 & 25,00 \\
\hline 13 & 24 & 26 & 15,00 & 25 & 21,00 \\
\hline 14 & 29,67 & 29 & 19,00 & 27 & 32,00 \\
\hline 15 & 34,33 & 33 & 27,00 & 28 & 31,00 \\
\hline 16 & 30 & 34 & 31,00 & 30 & 32,00 \\
\hline 17 & 30 & 35 & 22,00 & 31 & 23,00 \\
\hline 18 & 33 & 38 & 30,00 & 32 & 30,00 \\
\hline 19 & 29 & 40 & 19,00 & 36 & 28,00 \\
\hline & & & & 37 & 31,00 \\
\hline & & & & 39 & 20,00 \\
\hline & & & & 41 & 42,00 \\
\hline
\end{tabular}


Individual Scores on the L2 SST

\begin{tabular}{|l|c|c|c|c|c|}
\hline \multicolumn{2}{|c|}{ Elementary group } & \multicolumn{2}{c|}{ Intermediate Group } & \multicolumn{2}{c|}{ Advanced group } \\
\hline Part. & & Part. & & Part. & \\
\hline & 16,67 & 1 & 17,00 & 2 & 25,00 \\
\hline & 14,67 & 7 & 19,00 & 3 & 17,00 \\
\hline & 12 & 8 & 18,00 & 4 & 19,00 \\
\hline & 7,67 & 9 & 7,00 & 5 & 26,00 \\
\hline & 15,33 & 11 & 4,00 & 6 & 9,00 \\
\hline & 19 & 12 & 10,00 & 10 & 15,00 \\
\hline & 19 & 13 & 4,00 & 14 & 7,00 \\
\hline & 20,67 & 17 & 13,00 & 15 & 18,00 \\
\hline & 20,67 & 19 & 11,00 & 16 & 16,00 \\
\hline & 12,67 & 22 & 11,00 & 18 & 23,00 \\
\hline & 15,33 & 23 & 15,00 & 20 & 23,00 \\
\hline & 22,67 & 24 & 9,00 & 21 & 16,00 \\
\hline & 18 & 26 & 15,00 & 25 & 19,00 \\
\hline & 14,67 & 29 & 14,00 & 27 & 18,00 \\
\hline & 19,33 & 33 & 20,00 & 28 & 17,00 \\
\hline & 6 & 34 & 13,00 & 30 & 24,00 \\
\hline & 20 & 35 & 7,00 & 31 & 14,00 \\
\hline & 10,67 & 38 & 11,00 & 32 & 21,00 \\
\hline & 10,33 & 40 & 9,00 & 36 & 32,00 \\
\hline & & & & 37 & 31,00 \\
\hline & & & & 39 & 7,00 \\
\hline & & & & 41 & 38,00 \\
\hline
\end{tabular}

Recebido em 05/06/2013. Aprovado em 27/11/2013. 